\title{
Why Singapore is what it now is
}

\section{Lee Kuan Yew}

Discurso pronunciado por el ex Primer Ministro (actual «Minister Mentor») de la República de Singapur, en la sesión inaugural de la Conferencia de la International Bar Association, realizada en el Suntec Convention Centre, el 14 de octubre de 2007

To understand Singapore, you have to know how we were suddenly thrown out of the Federation of Malaysia in 1965 and became an independent state. Peninsular Malaya had been Singapore's hinterland ever since the British founded Singapore in 1819.

We faced a bleak future. We had no natural resources. A small island-nation in the middle of newly independent and nationalistic countries of Indonesia and Malaysia, each determined to cut Singapore off as the middleman. To survive, we had to create a Singapore different from our neighbours -clean, more efficient, more secure, with quality infrastructure, and good living conditions. We sought to provide an environment that our neighbours did not provide -first world standards of reliability and predictability. Important for investors and economic growth, is the rule of law, implemented through an independent judiciary, an honest and efficient police force, and effective law enforcement agencies. Had we not differentiated Singapore in this way, it would have languished and perished as a shrinking trading centre and never become the thriving business, banking, shipping and civil aviation hub it is today.

I studied law in the Cambridge Law School and am a barrister of Middle Temple, an English Inn of Court. I had practised law for a decade before I first took office in 1959 as Prime Minister of self-governing Singapore. Therefore I knew that the rule of law would give Singapore an advantage in the 
centre of Southeast Asia where the law was often what was decided by the leader, whether a President or Prime Minister, often an ex-military man.

\section{The Singapore Approach to the Fundamentals}

- Singapore inherited a sound legal system from the British.

- Clear laws, easy access to justice and an efficient legal system provide the basis for citizens to compete equally in the market and to grow the economy.

- A stable and predictable legal environment facilitates the enforcement of contractual rights and protection of property rights.

- The common law heritage and its developed contract law are known to and have helped attract investors. Our laws relating to financial services are similar to the laws of leading financial centres in other common law jurisdictions such as London and New York. As these are the two leading financial centres in the world, their laws govern the majority of financial transactions worldwide. They are used freely in Singapore.

- Since 1959 we had adopted English as our working language.

- While we have kept key English legal principles; after the UK joined the EU, it adopted EU laws and doctrines. We have not followed them. Instead we have amended our laws to fit our needs and circumstances.

- The independence of our courts is protected by the constitution that prevents removal of judges from office by the executive. We established our own final Court of Appeal in place of the Privy Council as our courts would be more familiar with our own legislation and local conditions and culture.

- We still look to English precedents and examples, but increasingly we look also to those of US, Australia, New Zealand and other Commonwealth countries. Even civil law 
countries have given us useful concepts and ideas, especially those adopted and incorporated as part of UNCITRAL trade laws.

- We have special legislation to meet our needs:

- A multi-racial and multi-religious society is prone to conflicts. Race, language and religion in Singapore have to be handled sensitively, especially during elections. We have enacted the Religious Harmony Act, and set up the Presidential Council for Minority Rights. We created Group Representation Constituencies to ensure minority representation in Parliament.

- For good industrial relations, we enacted the Employment Act and Industrial Relations Act to provide the framework for our tripartite system of industrial relations, a system for collective bargaining, and an Industrial Arbitration Court to resolve industrial disputes.

- For law and order, we have strong deterrent sentences for offences like drug trafficking, kidnapping, unlawful possession of firearms.

- The Immigration Act provides for caning sentences to deter illegal immigrants and overstayers.

- For national security, the Internal Security Act allows for preventive detention, an effective response to terrorists.

\section{BENEFITS OF A SOUND LEGAL FRAMEWORK}

- By the 1980s the system of courts we inherited from the British could not cope with the increasing volume of work. It needed to be modernised and to make use of IT. This also needed a Chief Justice who is not only legally qualified, but also has managerial and administrative experience to reform the system.

- It was Chief Justice Yong Pung How (1990 to 2006) who had practiced law for over two decades before he became a merchant banker and finally Chairman of Singapore's largest bank. He restructured the system, instituted new procedures, used IT in the courts, increased the number of judges and 
courts and selected the most able and balanced of those at the Bar to become judges. The World Bank, in a report published in 2007 entitled "Judiciary led reforms in Singapore -framework strategies and lessons", stated: "Over the past 15 years, Singapore's judicial system has been transformed from one that many viewed as characterized by inefficiencies, delays, and inadequate administrative capacity to one widely seen as among the most efficient and effective in the world.» The Attorney General, Chan Sek Keong, who has since become Chief Justice, will maintain these standards.

- Good governance, a sound legal framework and judiciary have resulted in stability and economic growth and increasing demand for lawyers and legal services.

\section{Transparent administration of justice}

- Our emphasis is on meritocracy, the building blocks of sound governance and integrity in our judiciary and legal system. The integrity of our financial systems withstood the turbulence in the 1997 Asian financial crisis that caused several of our neighbours' banking systems to collapse. Singapore's firm regulatory framework has facilitated economic progress.

- Corruption, endemic in parts of the world, was seeping into Singapore in the 1950's when elections had introduced elected ministers in the transition to internal self-government. In 1959 when we took office in the first fully elected government, we moved swiftly to rid ourselves of corruption before it could become endemic.

- «Transparency International», a civil society organisation against corruption based in Berlin, has repeatedly listed Singapore in the first top five of 163 countries. And the only one from Asia in the first 5 .

- Our system does not tolerate corruption and we have avoided the problems of widespread corruption that have plagued Asia. Our Corrupt Practices Investigation Bureau (CPIB) annually tabulates the cases brought against officers and executives from the public and private sectors. In two cases, it led to the conviction and prison sentence of a junior 
Minister. Another, a cabinet Minister, committed suicide after being investigated for corruption.

- Three factors enabled Singapore to escape the poverty that plagued the region: first, clean and efficient government; second, the character and capabilities of the leadership in charge; third, an industrious people, eager and quick to learn to be productive and gainfully employed.

\section{Defamation}

- Political leaders in Singapore take action against opponents who make statements against them that impute dishonesty and lack of integrity. Situated in a region where 'money politics' is part of the political culture and an accepted way of life, any allegation of corruption in Singapore must be taken seriously. It leads to an investigation by the CPIB, and/or an action for defamation against the person making the allegation to clear any doubts on the integrity of the government.

- As a result people in Singapore do not equate their political leaders with second-hand car salesmen.

\section{Economic competitiveness}

- International surveys of economic competitiveness of countries always include the legal framework and the administration of justice as key criteria in ranking such countries.

- The Political and Risk Consultancy, World Economic Forum and other polls show that both foreigners and Singaporeans believe that we have good judicial and legal systems, and fair administration of justice.

- The Institute For Management Development (IMD) World Competitiveness Yearbook has consistently ranked Singapore in the top 2 positions since 1997 under the Legal Framework component. (This category examines if the legal and regulatory framework encourages the competitiveness of enterprises.)

- The World Bank released its study Doing Business Report 2007 in September 2006. Singapore fared better in 
2006 as compared to the previous year, and has replaced New Zealand at the top spot.

\section{GLOBALISATION AND HOW OUR LEGAL INFRASTRUCTURE MUST TRANSFORM}

- Despite these endorsements, we cannot be complacent. We have to respond to new challenges that technology and globalisation have brought upon us.

- With technology increasingly sophisticated in a world that is increasingly borderless, crime has become multi-facetted, and multi-jurisdictional. Our legislative mechanisms have responded to meet these challenges. Many legal issues today require an international co-operation for solutions.

- Law firms are also taking advantage of new global business opportunities and technologies. US and British law firms are able to venture aggressively into new markets, following their clients' multi-jurisdictional businesses. Businesses span many countries and lawyers must meet the needs of their multi-national clientele.

\section{CONCLUSION}

- We need to maintain Singapore's position as a city par excellence, with an environment that is clean, safe and vibrant to work in and live in. We try to retain our best, and we attract the best to come, settle and raise their families here. 